\title{
KOHESI LEKSIKAL DALAM RUBRIK POLITIK SURAT KABAR KOMPAS
}

\author{
Puput Puji Lestari, Wiwik Darmini, Benedictus Sudiyana \\ ${ }^{123}$ Program Studi Pendidikan Bahasa dan Sastra Indonesia \\ Universitas Veteran Bangun Nusantara Sukoharjo \\ Author correspondence : benysudiyana@gmail.com
}

\begin{abstract}
Abstrak
Tujuan penelitian ini adalah mendeskripsikan penggunaan jenis kohesi leksikal yang terdapat dalam surat kabar Kompas edisi Desember 2015 dan implementasi sebagai bahan ajar bahasa Indonesia di SMK. Penelitian ini menggunakan metode deskriptif kualitatif. Data dalam penelitian ini berupa kata, frasa, dan kalimat-kalimat yang memuat penggunaan kohesi leksikal dalam surat kabar harian Kompas edisi Desember 2015 dan kohesi leksikal sebagai materi bahan ajar bahasa Indonesia di SMK. Sumber data penelitian ini yaitu surat kabar Kompas edisi 2015. Prosedur pengumpulan data menggunakan teknik pustaka, teknik baca, dan teknik catat. Prosedur analisis data menggunakan metode agih. mengumpulkan data, menggolongkan sesuai dengan jenis kohesi. Pemeriksaan keabsahan data menggunakan triangulasi peneliti. Hasil penelitian dapat disimpulkan bahwa terdapat enam jenis kohesi leksikal, repetisi, sinonimi, antonimi, hiponimi, kolokasi, dan ekuivalensi dalam surat kabar Kompas dan kohesi leksikal. Sebagai bahan ajar bahasa Indonesia di SMK materi kohesi menunjang kelengkapan materi klasifikasi kata berdasarkan bentuk kata, makna kata berdasarkan kelas kata, dan penggunaan kamus dalam mencari bentuk, kategori, dan makna kata.
\end{abstract}

Kata kunci: kohesi leksikal, kohesi leksikal

\begin{abstract}
The purpose of this study is to describe the use of the lexical cohesion types contained in the Kompas newspaper in the December 2015 edition and its implementation as Indonesian teaching material in vocational high schools. This study used descriptive qualitative method. The data are in the form of words, phrases, and sentences that contain the use of lexical cohesion in the December 2015 edition of the Kompas daily newspaper and lexical cohesion as Indonesian teaching material in SMK. The data source is the 2015 edition of Kompas newspaper. The procedure of data collection uses library techniques, reading techniques, and note taking techniques. The procedure of data analysis uses the distribution method. collecting data, classifying according to the cohesion types. Checking the validity of the data uses researcher triangulation. The results of the study concluded that there were six types of lexical cohesion, repetition, synonymy, antonymy, hyponymy, collocation, and equivalence in Kompas and lexical cohesion newspapers. As Indonesian teaching material in vocational high school cohesion material supports the completeness of word classification material based on word forms, word meanings based on word classes, and the use of dictionaries in searching for forms, categories, and word meanings.
\end{abstract}

Keywords: lexical cohesion, lexical cohesion 


\section{PENDAHULUAN}

Wacana tulis sebagai sarana komunikasi memegang peran yang sangat penting. Keutuhan makna suatu wacana dapat dicapai dengan adanya unsur kohesi dan koherensi. Dengan mengetahui karakteristik kohesi sebuah wacana diharapkan akan membantu memudahkan pemahaman sebuah wacana. Kohesi leksikal menampati posisi strategis karena mampu memberikan penekanan dan penegas dalam sebuah konteks yang sesuai untuk menggambarkan persamaan, perbedaan/pertentangan, peran, hasil, kedudukan, dan interaksi (Parwati, 2011).

Surat kabar harian Kompas terbit setiap hari. Berita dalam surat kabar tersebut tidak hanya menjangkau satu wilayah saja, namun dapat dijangkau oleh wilayah-wilayah lainnya di Indonesia. Kompas selalu menyuguhkan berita yang cepat dan hangat untuk diperbincangkan. Jangkauan peredaran Kompas yang cukup luas dan memungkinkan lebih lengkap untuk diteliti, baik dari segi bentuk, kata bacaan, kalimat, pemenggalan dalam kalimat, maupun struktur kalimatnya. Surat kabar harian Kompas terdiri dari beberapa rubrik antara lain politik, ekonomi, olahraga, kriminal, hukum dan lain-lain. Salah satu rubrik yang menarik untuk dibahas adalah kolom politik karena berita mengenai politik selalu ada yang menarik untuk dibaca. Kabar politik selalu membuat para pembaca merasa senang dan geram pada setiap beritanya.

Kaitannya dalam pembelajaran bahasa Indonesia di sekolah. Jenis Kohesi Leksikal dapat diimplementasikan ke dalam pembelajaran bahasa Indonesia di SMK kelas XI semester 1 karena pada standar kompetensi menuntut siswa untuk membaca memahami makna kata, bentuk kata, ungkapan, dan kalimat dalam konteks bekerja.

Berdasarkan ulasan tersebut, akan sangat menarik apabila meneliti secara ilmiah mengenai kohesi leksikal dalam rubrik politik dan implementasinya sebagai bahan ajar bahasa Indonesia di sekolah, guna penulis karya ilmiah dan siswa memiliki pengetahuan dalam menganalisis wacana.

Berdasarkan rumusan masalah yang dikemukakan, maka penelitian ini memiliki tujuan dan manfaat keilmuan, maka peneliti memiliki tujuan penelitian:

1. Memaparkan pemakaian kohesi leksikal dalam wacana rubrik politik surat kabar Kompas edisi Desember 2015.

2. Mendeskripsikan implementasi hasil penelitian tentang kohesi leksikal dalam wacana rubrik politik surat kabar Kompas edisi Desember 2015 sebagai bahan ajar bahasa Indonesia di SMK.

Kohesi leksikal adalah kohesi yang terbentuk oleh kosakata (Rustono dan Sari, 2011:28). Adapun yang menyatakan kohesi leksikal adalah hubungan semantik antarunsur pembentuk wacana dengan memanfaatkan unsur leksikal atau kata (Kushartanti dalam Parwati, 2011:3).

Pendapat lain oleh Sumarlam (2003:34) kohesi leksikal ialah alat kohesi dalam wacana yang berkaitan dengan hubungan antarunsur dalam wacana secara semantis dan bukan secara gramatikal. Kohesi leksikal mempunyai fungsi yang sangat penting dalam wacana karena tujuan digunakannya aspek-aspek leksikal itu diantaranya ialah untuk mendapatkan efek intensitas makna bahasa, kejelasan informasi dan keindahan bahasa lainnya (Mulyana, 2005:134).

Dengan demikian dapat disimpulkan kohesi leksikal merupakan salah satu unsur yang mempengaruhi terbentuknya wacana dengan memanfaatkan kata dan menganalisis berdasarkan makna. Kohesi leksikal dapat memperindah bahasa dalam sebuah wacana.

Banyak ahli mengklasifikasikan jenis kohesi leksikal secara berbeda-beda, salah satunya ialah pendapat Rani, Bustanul, dan Martutik (2006:129) yang secara umum piranti kohesi leksikal berupa kata atau frase bebas yang mampu mempertahankan hubungan kohesif dengan kalimat mendahului atau mengikuti. Menurut Rentel (Rani, Bustanul, dan Martutik 2006:129) piranti kohesi leksikal terdiri atas dua macam. Pertama, reiterasi (pengulangyaitu piranti kohesi yang digunakan dengan mengulang sesuatu preposisi atau bagian dari preposisi. Reiterasi itu meliputi repetisi (ulangan) dan ulangan hiponim antara lain ulangan penuh, ulangan dengan bentuk lain, ulangan dengan penggantian, dan ulangan dengan hiponim. Kedua, kolokasi kata yang menunjukkan adanya hubungan kedekatan tempat (lokasi).

Secara lengkap jenis kohesi leksikal Sumarlam (2003:34) membatasi jenis kohesi leksikal dalam wacana menjadi enam macam yaitu: (1) Repetisi, (2) Sinonimi, (3) Antonimi, (4) Kolokasi, (5) Hiponimi, dan (6) Ekuivalensi. Jenis kohesi leksikal tersebut masih dispesifikasikan berdasarkan 
jenisnya. Beberapa jenis dari pengertian kohesi leksikal peneliti mengambil jenis kohesi leksikal dari Sumarlam, karena paling lengkap diantara teori yang lain dan penjabarannya lebih jelas. Keenam cara untuk mencapai kepaduan wacana melalui aspek leksikal itu akan diuraikan pada bagian-bagian di bawah ini.

Repetisi adalah pengulangan satuan lingual (bunyi, suku kata, kata, atau bagian kalimat) yang dianggap penting untuk memberi tekanan dalam sebuah konteks yang sesuai (Sumarlam, 2003:34). Repetisi atau ulangan merupakan salah satu cara untuk mempertahankan hubungan kohesif antar kalimat, hubungan itu dibentuk dengan mengulang sebagian kalimat (Rani, Bustanul, dan Martutik 2006:130).

Berdasarkan tempat satuan lingual yang diulang dalam baris, klausa atau kalimat, repetisi dapat dibedakan menjadi delapan macam, yaitu repetisi epizeuksis, tautotes, anafora, epistrofa, simploke, mesodiplosis, epanalepsis, dan anadiplosis (Sumarlam, 2003:34). Berikut adalah penjelasan dari kedelapan jenis repetisi tersebut.

Beberapa ahli mendefinisikan repetisi epizeukis, dimana repetisi epizeuksis ini merupakan salah satu dari beberapa jenis repetisi. Repetisi epizeuksis merupakan pengulangan satuan lingual (kata) yang dipentingkan beberapa kali secara berturut-turut. Ahli lain seperti (Keraf, 2004:127; Parwati, 2011:4) repetisi epizeuksis adalah repetisi yang bersifat langsung, artinya kata yang dipentingkan diulang beberapa kali berturut-turut.

Setelah mengumpulkan beberapa teori di atas dapat disimpulkan bahwa repetisi epizeuksis merupakan pengulangan yang terjadi secara beberapa kali dan bersifat langsung. Jenis repetisi ini berfungsi memperjelas atau memberi penekanan terhadap sebuah wacana.

Repetisi tautotes ialah pengulangan satuan lingual (sebuah kata) beberapa kali dalam sebuah kontruksi (Sumarlam, 2003:35; Keraf 2004:127; dan Parwati, 2011:4). Secara garis besar dapat disimpulkan repetisi tautotes merupakan repetisi yang terjadi secara berulang-ulang dalam sebuah wacana. Sama halnya dengan jenis repetisi yang lain, repetisi tautotes mempunyai fungsi untuk memberi penekanan dan efek keindahan dalam sebuah wacana.

Repetisi anafora adalah pengulangan satuan lingual berupa kata atau frasa pertama pada tiap baris atau kalimat berikutnya (Sumarlam, 2003:35; Keraf, 2004:127; Parwati, 2011:4). Setelah mengumpulkan dari beberapa teori di atas dapat disimpulkan bahwa repetisi tautotes merupakan repetisi yang terletak pada kata pertama disetiap barisnya. Fungsinya ialah untuk menekankan kata tersebut dan memberi keindahan sebuah wacana.

Repetisi epistrofa ialah pengulangan satuan lingual kata/frasa pda akhir baris (dalam puisi) atau akhir kalimat (dalam prosa) secara berturut-berturut (Sumarlam, 2003:35; Keraf, 2004:128; dan Parwati, 2011:4). Secara garis besar dapat disimpulkan repetisi epistrofa merupakan repetisi yang terjadi pada akhir kalimat atau prosa secara berturut-turut.

Repetisi simploke adalah repetisi pada awal dan akhir beberapa baris atau kalimat berturutturut, (Sumarlam, 2003:36; Parwati, 2011:4; dan Keraf, 2004:128). Secara garis besar simpulan dari beberapa teori di atas ialah repetisi simploke merupakan repetisi yang terjadi pada setiap awal dan akhir kalimat. Tujuannya ialah untuk memperindah dan memperjelas sebuah wacana.

Repetisi mesodiplosis adalah pengulangan satuan lingual di tengah-tengah baris atau kalimat secara berturut-turut (Sumarlam, 2003:36). Tidak jauh berbeda dengan Keraf (2004:128) repetisi mesodiplosis merupakan repetisi di tengah baris-baris atau kalimat berturut-turut. Pendapat lain oleh Tarigan (Parwati, 2011:4) mengungkapkan bahwa repetisi mesodiplosis adalah repetisi yang berwujud perulangan kata atau frase di tengah-tengah baris atau beberapa kalimat.

Setelah membaca beberapa teori di atas repetisi mesodiplosis ialah repetisi yang terjadi pada tengah-tengah baris. Tujuan dari repetisi tersebut ialah untuk menekankan kata tersebut dan dapat memperindah sebuah wacana.

Repetisi epanalepsis ialah pengulangan satuan lingual, yang kata/frasa terakhir dari baris/kalimat itu merupakan pengulangan kata/frasa pertama (Sumarlam, 2003:37; Keraf, 2004:128; Parwati, 2011:4). Repetisi anadiplosis kata atau frasa terakhir dari suatu klausa atau kalimat menjadi kata atau frasa pertama dari klausa atau kalimat berikutnya (Keraf, 2004:128; Sumarlam, 2003:37; Parwati, 2011:4). Secara garis besar pendapat dari beberapa ahli tersebut dapat disimpulkan repetisi 
anadiplosis merupakan repetisi yang terjadi pada kata terakhir yang dimana kata tersebut kemudian menjadi kata utama pada kalimat berikutnya.

Secara etimologi kata sinonimi berasal dari bahasa Yunani kuno, yaitu onoma yang berarti 'nama', dan syn yang berati 'dengan'. Maka secara harfiah kata sinonimi berarti nama lain untuk benda atau hal yang sama (Chaer, 2009; Sumarlam (2003). Sinonimi kata dengan frasa atau sebaliknya dapat dilihat pada contoh berikut ini: Kota itu semalam dilanda hujan dan badai. Akibat adanya musibah itu banyak gedung yang runtu, rumah-rumah penduduk roboh, dan pohon-pohon tumbang disapu badai (Sumarlam, 2003:38).

Antonimi berasal dari kata Yunani Kuno, yaitu onoma yang berarti nama dan anti yang artinya melawan. Secara harfiah antonim berarti nama lain untuk benda lain pula (Chaer, 2009; Sumarlam, 2003).

Tidak jauh berbeda dengan Verhaar (Chaer 2009:89) antonimi merupakan ungkapan yang biasa berupa kata, tetapi dapat pula dalam bentuk frase atau kalimat) yang maknanya dianggap kebalikan dari makna ungkapan lain. Dengan demikian dapat disimpulkan bahwa antonimi merupakan nama lain untuk benda yang lain dan sifatnya berlawanan bisa disebut juga lawan makna.

Berdasarkan sifatnya, Sumarlam (2003:39) membagi oposisi makna dapat dibagi atas lima macam yakni:

Oposisi mutlak adalah pertentangan makna secara mutlak, misalnya oposisi antara kata hidup dengan kata mati (Sumarlam, 2003:39). Ahli lain seperti Suwandi (2011:131) antonimi mutlak muncul apabila pertentangan antara kata atau bentuk bahasa yang memiliki hubungan antonim tersebut bersifat mutlak. Pengertian antara kedua kata atau bentuk itu terdapat batas yang mutlak.

Menurut Suwandi (2011:132) kata-kata atau bentuk-bentuk bahasa yang termasuk jenis antonim gradasi atau oposisi kutub mempunyai pertentangan yang tidak mutlak. Ketidakmutlakan makna pada oposisi terletak pada asanya tingkat gradasi pada kata-kata tersebut.

Chaer (2009:93) makna kata-kata yang beroposisi hierarkial ini menyatakan suatu deret jenjang atau tingkatan. Oleh karena itu kata-kata yang beroposisi hierarkial ini adalah kata-kata yang berupa nama satuan ukuran (berat, panjang, dan isi), nama satuan hitungan penggalan, nama jenjang kepangkatan dan sebagainya. Kata-kata yang termasuk antonimi hierarkial adalah nama satuan waktu (berat, panjang, isi), nama satuan hitungan dan penanggalan, nama satuan jenjang kepangkatan, dan sebagainya (Suwandi, 2011:133).

Berdasarkan beberapa teori di atas dapat ditarik simpulan oposisi hierarkial merupakan repetisi yang menyatakan deret suatu jenjang. Jenjang tersebut bisa deret jenjang pendidikan, deret satuan berat dan lain sebagainya.

Oposisi majemuk adalah oposisi makna yang terjadi pada beberapa kata. Perbedaan antara oposisi majemuk dengan oposisi kutub terletak pada ada tidaknya gradasi yang dibuktikan dengan dimungkinkannya bersanding dengan kata agak, lebih, dan sangat. Pada oposisi kutub, dan tidak ada oposisi majemuk (Sumarlam, 2003:93).

Pendapat lain oleh Chaer (2009:93) oposisi majemuk merupakan perbendaharaan kata Indonesia ada kata-kata yang beroposisi terhadap lebih dari sebuah kata. Lebih jelasnya oleh Keraf (2004:40) oposisi majemuk merupakan oposisi yang mencakup suatu perangkat yang terdiri dari dua kata. Oposisi ini bertalian terutama hipinim-hiponim dalam satu kelas. Dengan demikian dapat disimpulkan oposisi majemuk merupakan oposisi yang terdiri dari beberapa kata.

Kolokasi merupakan suatu hal yang selalu berdekatan atau berdampingan dengan yang lain biasanya diasosiasikan sebagai satu kesatuan (Rani, dkk; 2006:133). Pendapat lain oleh Kusrianti dkk (2006:10) kolokasi atau sanding kata adalah asosiasi tertentu dalam menggunakan pilihan kata yang cenderung digunakan secara berdampingangan.

Istilah hipomim berasal dari kata Yunani Kuno onoma (nama) dan hypo (di bawah) artinya hiponim merupakan nama yang termasuk di bawah nama lain (Djajasudarma, 2009; Sumarlam, 2003; Zaimar dan Ayu, 2011)

Ekuivalensi adalah hubungan kesepadanan antara satuan lingual tertentu dengan satuan lingual yang lain dalam sebuah paradigma. Dalam hal ini sejumlah kata hasil proses afiksasi dari morfem asal yang sama menunjukkan adanya hubungan kesepadanan (Sumarlam, 2003:44). 
Analisis wacana merupakan suatu kajian yang meneliti atau menganalisis bahasa yang digunakan secara alamiah, baik dalam bentuk lisan maupun tulisan (Stubs dalam Badara, 2013:18). Pendapat lain oleh (Mulyana, 2005:69) analisis wacana merujuk pada upaya mengkaji pengaturan bahasa di atas klausa dan kalimat, dan karenanya juga menguji satuan-satuan kebahasaan yang lebih luas. Seperti pertukaran percakapan atau bahasa tulis. Konsekuensinya, analisis wacana juga memperhatikan bahasa pada waktu digunakan dalam konteks sosial, khusunya interaksi antar penutur.

Wacana adalah satuan bahasa yang terlengkap dan terbesar/tertinggi di atas kalimat atau klausa dengan koherensi dan kohesi yang berkesinambungan, yang mempunyai awal dan akhir yang nyata disampaikan secara lisan atau tertulis (Tarigan, 2009; Mulyana, 2005.

Pengertian dari teori-teori di atas diperlengkap menjadi wacana merupakan satuan bahasa yang paling besar yang digunakan dalam komunikasi. Satuan di bawahnya secara berturut-turut adalah kalimat, frase, kata, dan bunyi (Rani, Bustanul, Martutik, 2006:3). Selanjutnya Jorgensen dan Phillips (2007:1) wacana adalah gagasan umum bahwa bahasa ditata menurut pola-pola yang berbeda yang diikuti oleh ujaran para pengguna bahasa ketika mereka ambil bagian dalam domain-domain kehidupan sosial yang berbeda, misalnya dalam domain "wacana medis" dan "wacana politik".

Kohesi leksikal atau aspek yang menyatakan hubungan makna. Pada proses pembelajaran di SMK terdapat pembelajaran mengenai makna kata yang tertera pada silabus SMK kelas XI semester 1 dengan SK (Standar Kompetensi) berkomunikasi dengan bahasa Indonesia secara tingkat Madya, KD (Kompetensi Dasar) membaca untuk memahami makna kata, bentuk kata, ungkapan, dan kalimat dalam konteks bekerja, Indikator: (a) Mengelompokkan kata, bentuk kata, ungkapan, dan kalimat berdasarkan kelas kata dan makna kata, (b) Mendaftar kata-kata yang berpotensi memiliki sinonim dan antonim dalam teks bacaan, (c) Mengidentifikasi kata (termasuk bentuk kata baru), frasa, kalimat yang dipersoalkan kebenaran/ketepatannya (diterima/ditolak) berdasarkan paradigma atau analogi, (d) Mengidentifikasi kata, frasa, kalimat atau bentuk kata baru yang perlu dipersoalkan kebenarannya/ketepatannya (diterima/ditolak) berdasarkan kaidah atau kelaziman.

Materi pembelajaran berupa informasi mengenai (a) hubungan antara makna kata, bentuk kata, dan pemakaian kata dalam konteks bekerja (b) peran dan manfaat kamus dalam belajar bahasa dan dalam kehidupan berbahasa dan bernegara (c) proses pembentukan kata baru (d) relasi makna (sinonim, dan antonim), ungkapan idiomatik, dan bentuk kata.

Menurut Majid (2007:174), bahan ajar adalah segala bentuk bahan, informasi, alat dan teks yang digunakan untuk membantu guru/instruktur dalam melaksanakan kegiatan belajar mengajar. Bahan yang dimaksud bisa berupa tertulis maupun bahan yang tidak tertulis. Bahan ajar atau materi kurikulum (curriculum material) adalah isi atau muatan kurikulum yang harus dipahami oleh siswa dalam upaya mencapai tujuan kurikulum. Pandangan dari ahli lainnya mengatakan bahwa bahan ajar adalah seperangkat materi yang disusun secara sistematis, baik tertulis maupun tidak tertulis, sehingga tercipta lingkungan atau suasana yang memungkinkan peserta didik untuk belajar (Prastowo dalam Rosidah, 2013:04).

Penelitian oleh Rokhanah (2013) menguraikan hasilnya, yakni bahwa aspek kohesi leksikal yang ditemukan ada lima jenis penanda. Kelima jenis penanda kohesi leksikal meliputi: repetisi, sinonimi, antonimi, kolokasi, dan hiponim. Dalam kaitannya dengan aspek leksikal, analisis ini menemukan (i) repetisi yang muncul ada enam jenis repetisi, yaitu repetisi epizeuksis, repetisi anadiplosis, repetisi mesodiplosis, repetisi anafora, repetisi epistrofa, dan repetisi tautotes; (ii) sinonim kata dengan kata, kata dengan frasa dan sebaliknya, frasa dengan frasa, dan klausa dengan klausa; (iii) lima macam antonim yang ada, yaitu antonim mutlak, antonim gradasi/kutub, antonim hubungan, antonim hirarkial, dan antonim resiprokal; (iv kolokasi (sanding kata); (v) hiponim (hubungan atasbawah) yang melibatkan hipernim (superordinat).

\section{METODE PENELITIAN}

Metode penelitian yang digunakan ialah metode kualitatif deksriptif. Penggunaan metode ini bertujuan untuk mendeksripsikan rencana penelitian sesuai dengan masalah yang akan dikaji yakni kohesi leksikal dalam wacana rubrik politik surat kabar Kompas dan implementasi kohesi leksikal sebagai bahan ajar bahasa Indonesia di SMK. Metode digunakan untuk ini memaparkan jenis kohesi 
leksikal di antara repetisi, sinonimi, antonimi, kolokasi, hiponimi, dan ekuivalensi selanjutnya implementasi sebagai bahan ajar bahasa Indonesia di SMK.

Cara menggunakan metode ini adalah data yang dikumpulkan terutama berupa kata-kata, kalimat atau gambar yang memiliki arti lebih bermakna dan mampu memacu timbulnya pemahaman yang lebih nyata daripada sekedar sajian angka atau frekuensi. Peneliti menekankan catatan dengan deskripsi kalimat yang rinci, lengkap, dan mendalam yang menggambarkan situasi sebenarnya guna mendukung penyajian data (Sutopo, 2006:40).

Data dalam penelitian ini yakni berupa kata-kata, kalimat-kalimat yang mengandung jenis kohesi leksikal. Sumber data yang digunakan ialah surat kabar harian Kompas edisi Desember 2015. Tidak semua wacana dalam surat kabar Kompas menjadi data karena pada surat kabar Kompas terdapat beberapa jenis rubrik, tetapi hanya pada wacana rubrik politik. Pemahaman mengenai sumber data dalam penelitian sangat penting untuk bisa menghasilkan data yang lengkap, benar, dan sahih sehingga penelitiannya akan menghasilkan pemahaman dengan simpulan yang tepat (Nugrahani, 2014:108).

Pengumpulan data dalam penelitian ini menggunakan teknik pustaka, baca, dan catat. Teknik pustaka merupakan teknik yang menggunakan sumber-sumber tertulis untuk memperoleh data (Subroto, 1992:42). Sumber tertulis yang digunakan adalah wacana yang berasal dari objek penelitian yakni wacana tulis yang terdapat surat kabar harian harian Kompas edisi Desember 2015.

Langkah selanjutnya ialah membaca secara teliti dan cermat serta berulang-ulang agar memperoleh kata-kata atau kalimat-kalimat yang mengandung kohesi leksikal di dalamnya. Tujuan utama dalam membaca adalah untuk mencari serta memperoleh informasi, mencakup isi, memahami makna bacaan (Tarigan, 2013:9).

Teknik catat merupakan kelanjutan dari teknik membaca, pada teknik ini mencatat beberapa kata atau kalimat yang mengandung tujuan aspek kohesi leksikal dalam surat kabar harian Kompas edisi Desember 2015 yang akan dijadikan data. Tujuan teknik ini ialah agar data yang digunakan tidak mudah hilang atau rusak.

Teknik analisis data dilakukan dengan cara mendeskripsikan semua jenis yang termasuk kohesi leksikal. Kemudian diklasifikasikan sesuai dengan jenis kohesi leksikal. Teknik analisis yang digunakan ialah dengan menggunakan metode agih, dimana metode agih alat penentunya justru bagian dari bahasa yang bersangkutan itu sendiri. Alat penentu dalam rangka kerja metode agih itu jelas selalu berupa bagian unsur dari bahasa objek sasaran penelitian itu sendiri, seperti kata preposisi, adverbia, dan lain-lain (Sudaryanto, 2015:18).

\section{HASIL DAN PEMBAHASAN}

\section{Jenis Kohesi Leksikal dalam Wacana Rubrik Politik Surat Kabar Kompas Edisi Desember} 2015

Jenis kohesi leksikal yang ditemukan terbagi menjadi enam yakni kohesi leksikal jenis repetisi, sinonimi, antonimi, hiponimi, kolokasi, dan ekuivalensi. Agar lebih praktis dan mudah dipahami data dalam uraian berikut ini tidak semua data yang ditemukan dibahas satu per satu dalam bab ini. Uraian secara jelas dapat dilihat di bawah ini:

\section{a. Kohesi Leksikal Repetisi}

Repetisi merupakan pengulangan satuan bunyi berupa kata, frasa, atau kalimat yang dianggap penting untuk memberi tekanan. Data berupa repetisi yang ditemukan berupa:

1) Repetisi Epizeuksis

Repetisi epizeuksis merupakan pengulangan yang terjadi beberapa kali secara berturut-turut dalam sebuah kalimat atau wacana. Berikut data-data yang ditemukan dalam wacana rubrik politik surat kabar Kompas edisi Desember 2015 sebagai berikut.

(1) Fraksi Partai Golkar, Fraksi Partai Gerindra, dan Fraksi Partai Persatuan Pembangunan (PPP) meminta agar MKD tidak menjadwalkan persidangan sebelum verifikasi alat bukti serta laporan Menteri Energi dan Sumber Daya Mineral Sudirman Said tuntas dilakukan $(K / 01 / 12 / 2015: 02)$. 
(2) Presiden beranggapan bahwa helikopter yang ada bisa dioptimalkan. Namun, kata Pramono, pengadaan helikopter untuk cadangan tetap perlu dipikirkan karena helikopter yang dipakai presiden saat ini belum ada cadangannya ( K/04/12/2015:04).

Pada tuturan di atas terjadi pengulangan frasa fraksi partai pada tuturan (1), dan kata helikopter pada tuturan (2). Pengulangan frasa fraksi partai dan kata helikopter pengulangan terjadi secara berturutturut. Fungsi repetisi jenis ini ialah untuk menekankan betapa pentingnya frasa dan kata yang diulang tersebut.

2) Repetisi Mesodiplosis

Repetisi mesodiplosis merupakan pengulangan satuan lingual yang terjadi di tengah-tengah baris atau kalimat secara berturut-turut. Berikut contoh tuturan yang ditemukan.

(3) Bisa saja memilih lima orang, tetapi bisa juga memilih dua atau tiga orang, tergantung berapa calon pimpinan yang memenuhi persyaratan undang-undang Desmond $(K / 02 / 12 / 2015: 03 /)$.

(4) Ini sudah (terjadi) sejak tahun 2013. Kami sekarang minta mereka yang diduga menerima untuk kooperatif. Kalau memang menerima uang suap itu, kembaliakn saja sekarang, termasuk anggota DPRD periode sebelumnya," ujar Udnan Pandu Praja di Jakarta, Rabu $(2 / 12)(K / 03 / 12 / 2015: 03)$.

3) Repetisi Epistrofa

Repetisi epistrofa merupakan pengulangan satuan lingual kata/frasa yang terletak pada akhir baris (dalam puisi) atau akhir kalimat (dalam prosa) secara berturut-berturut. Berikut ini tuturannya:

(5) "Saudara anggota DPR, kan?

Ada sumpahnya kan?

ingat apa isi sumpahnya?"cecar Artha

“enggak ingat semuanya. Intinya tidak boleh menerima suap,"ujar Rio terbata-bata $(K / 01 / 12 / 2015: 03)$.

(6) "Sudah ada dugaan pelanggaran etika yang jelas, maka MKD sebaiknya fokus saja. Apakah ada pertemuan itu? Siapa yang menginisiasi pertemuan? Apa motif dari pertemuan? (K/07/12/2015:02)

4) Repetisi Anadiplosis

Repetisi anadiplosis merupakan pengulangan yang terjadi pada kata atau frasa terakhir dari suatu klausa atau kalimat yang menjadi kata atau frasa pertama dari klausa atau kalimat berikutnya. Berikut contoh repetisi anadiplosis yang ditemukan.

(7) Tikus diibaratkan sebagai koruptor dan cicak sebagai komisi pemberantasan korupsi $(K P K)$. $K P K$ sebagai anak kandung reformasi diharapkan memburu koruptor yang gemar merampok uang negara $(K / 06 / 12 / 2015: 02)$.

(8) Menurut Ardhiyatul, pameran tersebut dimaksudkan untuk membentuk kesadaran masyarakat tentang pentingnya melawan korupsi. Korupsi di negeri ini sudah akut sehingga perang untuk melawannya mesti dilakukan dengan berbagai cara, termasuk lewat seni $(K / 06 / 12 / 2015: 02)$.

Repetisi anadiplosis terjadi pada pengulangan kata $K P K$ dan Korupsi. Penggunaan kata $K P K$ pada tuturan (7) terletak di akhir kalimat, kemudian kata $K P K$ diulang kembali menjadi kata yang terletak di awal kalimat berikutnya. Sama halnya dengan tuturan (8) kata korupsi terletak pada akhir kalimat kemudian kata korupsi tersebut di ulang kembali pada awal kalimat.

\section{b. Kohesi Leksikal Sinonimi}

Sinonimi merupakan ungkapan (bisa berupa kata, frase, atau kalimat) yang maknanya kurang lebih sama dengan makna ungkapan lain. Data sinonimi yang ditemukan antara lain:

Sinonimi kata dengan kata

(9) Rapat pleno komisi III DPR, semalam memutuskan, menyepakati uji kelayakan dan kepatutan capim KPK dilaksanakan pada 14, 15, 16 Desember (K/02/12/2015:02). 
(10) Kerja politik sangat transaksional, tanpa etika dan tanpa sikap kenegarawanan $(K / 02 / 12 / 2015: 03)$.

\section{c. Antonimi}

1) Oposisi kutub

Oposisi kutub adalah oposisi makna yang tidak bersifat mutlak tetapi bersifat gradasi. Artinya, terdapat tingkatan makna pada kata-kata tersebut. Berikut contoh berupa tuturan jenis oposisi kutub.

(11) Rapat saat itu juga telah memutuskan menyidangkan perkara Setya secara terbuka kecuali pihak yang dimintai keterangan meminta berlangsung tertutup (K/01/12/2015:04).

(12) Pilkada langsung membuat korupsi semakin masif. Kelas menengah atas memilih golput, sedangkan kelas menengah bawah berprinsip "wani pira" (K/01/12/2015:04).

Kata yang menunjukkan penggunaan oposisi kutub yakni pada terbuka dan tertutup pada tuturan (11), kata atas dan bawah pada tuturan (12). Kata-kata yang dicetak miring tersebut mempunyai makna yang berbeda dan adanya gradasi, yaitu realitas terbuka lebar, tertutup rapat, paling atas, tengah, paling bawah.

1) Oposisi Hubungan

Oposisi hubungan merupakan oposisi makna yang bersifat saling melengkapi. Berikut contoh tuturan yang menunjukan oposisi hubungan.

(13) Bahwa memulai tindakannya Ketua DPR diduga mendahulukan kepentingan pribadi dan kelompok daripada kepentingan negara, jelas bertentang dengan kewajibannya sebagai anggota DPR (K/01/12/2015:04).

(14) Pelaksana tugas wakil ketua KPK Johan Budi SP mengatakan dari posisi dugaan tindak pidana, RT diduga sebagai pemberi, sementara TSS dan SMH sebagai penerima untuk memuluskan pengesahan RAPBD 2016 terkait pembentukan Bank Banten $(K / 03 / 12 / 2015: 03)$.

Pada contoh kalimat-kalimat di atas oposisi hubungan terletak pada kata ketua DPR dan anggota DPR pada tuturan (13) dan kata pemberi dan penerima pada tuturan (14). Kata-kata tersebut merupakan kata yang mempunyai makna berbeda tetapi memiliki hubungan. Ketua DPR tidak ada gunanya tanpa adanya anggota $D P R$ begitu pun pada kata pemberi, tidak ada gunanya kalau tidak ada penerima.

2) oposisi hierarkial

Oposisi hirarkial adalah oposisi makna yang menyatakan deret jenjang atau tingkatan, katakata yang menunjukan hiearkial seperti pada nama-nama satuan ukuran (panjang, berat, isi), nama satuan hitungan, penanggalan, dan sejenisnya. Berikut ini contohnya.

(15) Situs layanan analisis media sosial topsy.com mencatat, dari Selasa siang hingga sore ada lebih dari 3000 cuitan dengan kata kunci Papa Minta Saham (K/03/12/2015:03).

(16) Jumlah terdakwa korupsi yang diseret ke pengadilan oleh KPK bahkan meningkat dari 36 orang pada 2012 menjadi 41 orang pada 2013, dan 50 orang pada 2014 $(K / 02 / 12 / 2015: 03)$.

\section{d. Kolokasi}

Kolokasi merupakan suatu hal yang selalu berdekatan atau berdampingan dengan yang lain biasanya diasosiasikan sebagai satu kesatuan. contoh yang ditemukan antara lain:

(17) Pemerataan guru masih menjadi kendala. Di beberapa tempat banyak sekolah kelebihan guru, sementara sejumlah sekolah di daerah terpencil justru kekurangan guru berkualitas $(K / 08 / 12 / 2015: 07)$. 
Contoh di atas kata yang berkolokasi yakni kata sekolah dan guru. Kedua kata tersebut selalu berdampingan dan satu kesatuan karena sekolah tidak akan berfungsi jika tidak adanya guru begitupun sebaliknya. Kata-kata yang berkolokasi tersebut mendukung sebuah kepaduan wacana.

\section{e. Hiponimi}

Hiponimi diartikan sebagai satuan bahasa (kata, frasa, kalimat) yang maknanya dianggap merupakan bagian dari makna satuan lingual yang lain. Unsur atau satuan lingual yang mencakupi beberapa unsur atau satuan yang berhiponim itu disebut "hipernim" atau "superordinat". Berikut tuturan yang ditemukan.

(18) Mengenai siapa saja yang dapat jadi pengadu, ada tiga pihak: pemimpin DPR, anggota DPR, dan masyarakat (K/01/12/2015:04).

(19) Senin malam lalu, Gubernur Banten Rano Karno menuturkan ada empat bank yang salah satunya akan dipilih untuk diakuisisi. Keempat bank itu adalah Bank Pundi,

\section{f) Ekuivalensi} Windu Kentjana, MNC, dan Panin Syariah ( K/02/12/2015:15).

Ekuivalensi merupakan hubungan kesepadanan antara satuan lingual tertentu dengan satuan lingual yang lain dalam sebuah paradigma dan hasil proses afiksasi dari morfem asal yang sama menunjukkan adanya hubungan kesepadanan. Contoh tuturan yang ditemukan antara lain.

(20) Terlihat dari perdebatan teknis yang dapat mengganggu kelanjutan kasus ini. Ada dua hal yang diperdebatkan, yakni kedudukan hukum pengadu dan alat bukti (K/01/12/2015:04).

(21) Penggantian pemain dan perubahan arah permainan yang sementara di MKD itu tak ayal memunculkan pertanyaan siapa sebenarnya para pemain baru yang dimasukkan Fraksi Partai Golkar ke dalam MKD? (K/02/12/2015:02).

\section{Kohesi Leksikal dalam Wacana Rubrik Politik Surat Kabar Kompas Edisi Desember 2015 sebagai Materi Bahan Ajar di SMK}

Kaitannya dalam pembelajaran bahasa Indonesia jenis kohesi Leksikal yang berhubungan dengan makna kata dapat digunakan sebagai bahan pembelajaran bahasa Indonesia di Sekolah Menengah Kejuruan (SMK) kelas XI semester 1 dengan SK dan KD berikut ini:

Tabel Fragmentasi Silabus Aspek Keterampilan berbahasa dalam Kurikulum KTSP Kelas XI SMK

\begin{tabular}{|c|c|c|c|c|}
\hline No & $\begin{array}{c}\text { Aspek } \\
\text { Keterampilan } \\
\text { Berbahasa }\end{array}$ & Standar Kompetensi & Kompetensi Dasar & $\begin{array}{c}\text { Kelas/ } \\
\text { Semester }\end{array}$ \\
\hline 1 & Membaca & $\begin{array}{l}\text { 3. Berkomunikasi } \\
\text { dengan bahasa } \\
\text { Indonesia setara } \\
\text { tingkat Madya }\end{array}$ & $\begin{array}{l}2.4 \text { membaca untuk } \\
\text { memahami makna } \\
\text { kata, bentuk kata, } \\
\text { ungkapan, dan } \\
\text { kalimat dalam } \\
\text { konteks bekerja. }\end{array}$ & $\mathrm{XI} / 1$ \\
\hline
\end{tabular}

(sumber: silabus KTSP)

Penggalan silabus di atas menunjukkan implementasi bahan ajar materi salah satunya makna kata di dalam pembelajaran di SMK dalam aspek membaca untuk lebih jelasnya melihat silabus dengan melihat materi pokok yang harus dikuasai peserta didik. Dengan melihat Silabus Kurikulum Tingkat Satuan Pendidikan (KTSP) dalam penelitian ini dengan melihat silabus dapat dipaparkan beberapa 
materi menyangkut bahan ajar berupa kohesi leksikal yang berupa makna kata dan dapat ditunjang pengajarannya dengan penelitian ini antara lain:

a. Klasifikasi Kata berdasarkan Bentuk Kata

1. Kata Dasar

Kata dasar adalah kata yang tidak berimbuhan atau yang belum diberikan awalan, akhiran, sisipan, dan penggabungan awalan akhiran. Kata-kata seperti baik, getar, kerja, sakit, gunung disebut sebagai kata dasar karena kata-kata itu tidak berimbuhan atau belum diberi imbuhan.

2. Kata Turunan

Kata Turunan merupakan sebuah kata dapat menyampaikan beberapa pengertian melalui bentukan-bentukannya. Dari satu kata pula, kita dapat membuat atau mengembangkannya menjadi beberapa kata turunan. Dari kata turunan tersebut, kita dapat mengungkapkan satu bahkan beberapa ide/perasaan. Pemekaran kata dengan memberi imbuhan itu pun akan membuat kata-kata tersebut mengalami perubahan jenis atau kelas katanya.

3. Kata Ulang

Kata ulang adalah kata yang mengalami proses pengulangan bentuk baik seluruh kata maupun sebagian. Semua kata ulang wajib ditulis dengan memakai tanda penghubung (-). Contoh: lauk-pauk, mondar-mandir.

\section{Macam-macam kata ulang}

a) Ulangan seluruh kata dasar

Contoh: anak-anak, meja-meja, buku-buku, ibu-ibu, main-main, makan-makan

b) Ulangan kata dengan memberi imbuhan

Contoh: Berjalan-jalan

Bermanja-manja

c) Ulangan seluruh kata, namun terjadi perubahan suara pada kata yang kedua

Contoh: Caci-maki, Mondar-mandir

d) Ulangan seluruh kata yang dinamakan kata asal

Contoh: anai-nai, ubur-ubur

\section{b. Makna Kata Berdasarkan Kelas Kata}

Makna kata ialah pertalian antara bentuk dan referen (acuannya). Untuk mengetahui sebuah kata kita harus mengetahui bentuk dan referennya. Makna kata berdasarkan hubungan antarmakna terdiri atas sinonim, antonim, dan hiponim.

\section{c. Penggunaan Kamus dalam Mencari Bentuk, Kategori, dan Makna Kata}

Kamus dapat membantu seseorang untuk mencari variasi bentukan kata, kelas kata, dan contoh-contoh pemakaiannya, termasuk pelafalan, pedoman kata, dan bentuk ungkapannya. Kamus disusun berdasarkan abjad yang disertai penjelasan tentang makna dan pemakaiannya.

\section{SIMPULAN}

Berdasarkan hasil penelitian yang telah dijabarkan di atas dapat disimpulkan sebagai berikut:

1. Terdapat enam jenis kohesi leksikal yang terdapat dalam surat kabar Kompas, yaitu kohesi leksikal jenis repetisi (pengulangan), sinonimi (padan makna), antonimi (lawan makna), hiponimi, kolokasi dan ekuivalensi (kesepadanan) yang terdapat dalam rubrik politik pada edisi Desember 2015. Data yang berjumlah dengan penggunaan repetisi epizeuksis sebanyak 65 data, repetisi anadiplosis sebnayak 8 data, repetisi epistrofa sebanyak 2 data, dan repetisi mesodiplosis sebanyak 14 data. Jenis kohesi leksikal yakni sinonimi dengan jumlah data sebanyak 12, antonimi kutub sebanyak sebnayak 21 data, oposisi hubungan sebanyak 24 data, oposisi hierarkial sebanyak 9 data, hiponimi sebanyak 20 data, kolokasi sebanyak 1 data dan ekuivalensi sebanyak 45 data.

2. Kohesi leksikal dapat dipergunakan sebagai materi bahan ajar di SMK dengan SK berkomunikasi dengan bahasa Indonesia setara tingkat Madya, dapat ditunjang tersebut digunakan jika siswa mengalami kesulitan dalam mencari makna kata. dengan materi klasifikasi data berdasarkan bentuk kata, makna kata berdasarkan kelas kata, dan penggunaan kamus dalam mencari bentuk, kategori, dan makna kata. Penggunaan kamus 


\section{DAFTAR PUSTAKA}

Badara, Aris. 2012. Analisis Wacana Teori, Metode dan Penerapannya pada Wacana Media. Jakarta: Kencana.

Chaer, Abdul. 2009. Pengantar Semantik Bahasa Indonesia. Jakarta: Rineka Cipta.

Djajasudarma, T Fatimah. 2012. Wacana dan Pragmatik. Bandung: PT Refika Aditama

Irman, Mokhamad dkk. 2008. Bahasa Indonesia 2 : untuk SMK/MAK Semua Program Keahlian Kelas XI. Jakarta: Pusat Perbukuan, Departemen Pendidikan Nasional

Jorgensen, Marianne W dan Louise J Phillips. 2007. Analisis Wacana Teori dan Metode. Yogyakarta: Pustaka Belajar.

Keraf, Gorys. 2004. Diksi dan Gaya Bahasa. Jakarta: PT Gramedia Pustaka Utama

Kusrianti, dkk. 2004. Analisis Wacana: iklan lagu puisi cerpen novel drama. Bandung: PT Intan Sejati

Majid, Abdul. 2007. Perencanaan Pembelajaran. Bandung: PT Remaja Rosdakarya Offset.

Mulyana. 2005. Kajian Wacana Teori, Metode dan Aplikasin Prinsip-Prinsip Analisis Wacana. Yogyakarta: Tiara Wacana.

Nugrahani, Farida. 2014. Metode Penelitian Kualitatif. Solo: Cakra Books

Parwati, Edin. 2011. Kohesi Leksikal Repetisi pada Wacana "Wayang Durangpo" dalam Surat Kabar Harian Jawa Pos Edisi Februari-April 2010. Jurnal Artikulasi Vol.12 No.2. Hal 807

Rani, Abdul, Bustanul Arifin dan Martutik. 2006. Analisis Wacana Sebuah Kajian Bahasa dalam Pemakaian. Malang: Bayu Media Publishing.

Rohanah, Qudus. 2013. Analisis Kohesi Leksikal Dalam Novel Dom Sumurup Ing Banyu Karya Suparto Brata. Jurnal. Vol /02/ No. 01 /Mei2013. Hal:83 ejournal.umpwr.ac.id/index.php/aditya/article/view/398/420 diakses 09 April 2016 pukul 22.40.

Rustono dan Sari Sri Wahyuni. 2011. Kohesi Leksikal dan Kohesi Gramatikal dalam Karya Ilmiah Siswa SMA Sekota Semarang. Lingua Jurnal Bahasa dan Sastra Volume VII/1 Januari 2011. Hal:27

http://download.portalgaruda.org/article.php?article=137177\&val=5682\&title=KOHESI \%20LEKSIKAL\%20DAN\%20KOHESI\%20GRAMATIKAL\%20DALAM\%20KA RYA\%20ILMIAH\%20SISWA\%20SMA\%20SEKOTA\%20SEMARANG diakses pada 09 April 2016 pukul 23.10 
Subroto, Edi. 1992. Pengantar Metode Penelitian Linguistik Struktural. Surakarta: Sebelas Maret University Press.

Sudaryanto. 2015. Metode dan Teknik Analisis Bahasa. Yogyakarta: Sanata Dharma University Press

Sumarlam, dkk. 2003. Teori dan Praktik Analisis Wacana. Surakarta: Pustaka Cakra.

Sutopo. 2006. Metodologi Penelitian Kualitatif: Dasar Teori dan Penerapannya dalam Penelitian. Surakarta: Universitas Sebelas Maret

Suwandi, Sarwiji. 2011. Semantik Pengantar Kajian Makna. Yogyakarta: Media Perkasa Tarigan, Henri Guntur. 2009. Pengajaran Wacana. Bandung: Angkasa.

. 2013. Membaca: Sebagai Suatu Keterampilan Berbahasa. Bandung; Angkasa Zaimar, Oke Kusuma dan Ayu. 2011. Telaah Wacana Teori dan Penerapannya. Depok: PT Komodo Books 